GRADIATION\&APPLICATIONS

ISSN 2466-4294 (online) | rad-journal.org

Vol. 3 | Issue 1 | pp. 52-58, 2018

doi: 10.21175/RadJ.2018.01.010

Original research paper

\title{
RADON CONCENTRATION MEASUREMENTS AT THE IRT-SOFIA RESEARCH REACTOR SITE*
}

\author{
Aleksander Mladenov, Kiril Krezhov** \\ Institute for Nuclear Research and Nuclear Energy, Bulgarian Academy of Sciences, Sofia, Bulgaria
}

\begin{abstract}
We report on the findings from the radon monitoring in selected points of the IRT-Sofia nuclear site, which is an important part of radiation surveillance activities during the operation and maintenance of the facilities at the Nuclear Scientific Experimental and Educational Centre (NSEEC) of the Institute for Nuclear Research and Nuclear Energy. Consideration is given to the evidence prior and during the dismantling activities related to the IRT research reactor refurbishment project and after their accomplishment.
\end{abstract}

Key words: Management, research reactor, refurbishment, radioactive waste management, radon and thoron accumulation

\section{INTRODUCTION}

The professional experience of the employees of the Nuclear Scientific Experimental and Educational Center (NSEEC) at the Institute for Nuclear Research and Nuclear Energy (INRNE) in the field of radiation safety and protection has been addressed previously [1]-[4]. Here we draw attention to some aspects of the exposure to radon (Rn) and related occupational implications for the NSEEC personnel and the public.

Radon isotopes 222, 220 and 219 are radioactive gases produced by the disintegration of radium isotopes 226, 224 and 223, which are decay products of uranium-238, thorium-232 and uranium-235 respectively, and are found in the Earth's crust. Radon is an odourless and colourless radioactive gas that occurs naturally in the environment as a result of the decay of radium in soils, rocks and building materials. It is a noble gas and does not form chemical compounds. The ${ }^{222} \mathrm{Rn}$ half-life of 3.8 days is long enough for it to migrate from the rock producing it, through the soil, to the air. The processes of radon exhalation depend on a multitude of factors, including among the others the content and distribution of radium in the soil, the soil's grain size, porosity, and permeability, soil moisture content, the radon diffusion coefficient through fractures and interstitial pores, and environmental parameters (air and soil temperature, barometric pressure, rainfall, snowfall) [5]. Once detached from a geological or anthropogenic matrix, radon mobility in the atmosphere is governed only by diffusion and transport. For the theory of radon geogenic potential, the basic transport pathways and the definition of "radon-prone area", see e.g. [6]. In principle, maps of radon-prone areas are to be used as planning aids for administration purposes to estimate the necessary further efforts and preventive measures. The exposure of man to this alpha-particle-emitting gas is mainly to lung by inhalation. The indoor radon, thoron and their decay products from geogenic and/or anthropogenic origin are the main contributors of the total inhalation dose which has long been recognized as a potential radiological health hazard [7],[8]. The potential effects of radon on human health lie in its decay products rather than the gas itself. The risk of radon exposure is associated with high levels of radon concentration in confined environments and the subsequent inhalation, increasing the risk of damaging the organ cells where radon short-life products are deposited. In houses, building characteristics and lifestyle, i.e. often or forced ventilation, have a significant impact on radon entry and dilution by fresh atmospheric air. Generally, health effects of exposure to radon in indoor environments (indoor air) depend mainly on the concentration of inhaled radon, the ventilation rate of the place, frequency and duration of the exposure.

This work aimed to evaluate the equivalent dose rates in different workplaces of buildings located within the NSEEC protected site on the basis of measured radon concentrations using active sampling of indoor air. The main conclusions consider outdoor data and indoor measurements carried out in the bottom floors of buildings, which are in direct contact with the ground.

\section{NUCLEAR SITE DESCRIPTION}

The nuclear site of the NSEEC comprises the research reactor IRT-Sofia, presently shut down

\footnotetext{
* The paper was presented at the Fifth International Conference on Radiation and Applications in Various Fields of Research (RAD 2017), Budva, Montenegro, 2017.

knezhov@inrne.bas.bg
} 
because of undergoing reconstruction, two radiochemical workrooms, a ${ }^{60} \mathrm{Co}$ gamma irradiator, several radioactive waste (RAW) storages and a number of research laboratories that use radiation sources in their work. All the facilities and RAW storages convey issues that are imposing requirements for permanent dosimetric control and radiation monitoring of environment, Fig. 1.

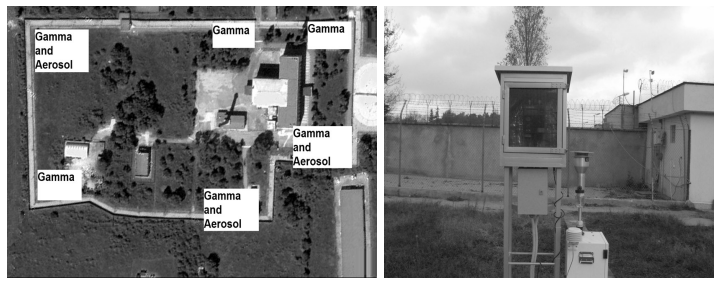

Figure 1. Radiation monitoring stations' disposition at the site

The major buildings inspected in this survey were the nuclear research reactor IRT-Sofia, where in its basement the First Class Radiochemical Laboratory is located (radiochemical niches, glove boxes etc. for radiopharmaceuticals, as well as a technological conveyor line passing through four hot cells for treatment of high specific activity radioactive isotopes), the building of the central alarm system and the auxiliary building wherein the laundry facilities and the ${ }^{60} \mathrm{Co}$ gamma irradiator GOU-1 are installed.

The stationary technological (gamma and neutron detectors) and environmental (gamma and aerosol detectors) monitoring systems (see Fig.2) are online 24 hours. Environmental monitoring via the automated and integrated radiation monitoring system (ARMS) involves: monitoring of gamma dose rate, alpha and beta activity, radon activity, ${ }^{218} \mathrm{Po},{ }^{214} \mathrm{Po}$ and ${ }^{212} \mathrm{Po}$ activity, gamma control of vehicles. Technological control of gaseous effluents from the facilities includes alpha beta particulate monitor, iodine monitor, noble gases monitor and stack flow monitor.

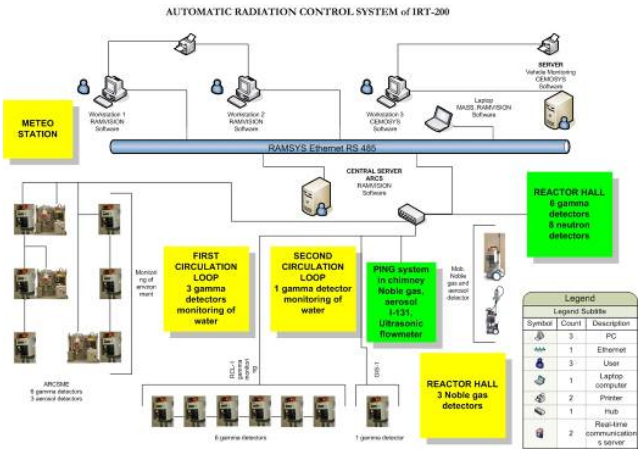

Figure 2. Schematic presentation of AMRS structure

The fully automated and integrated radiation monitoring system allows for the implementation of technological and environmental monitoring of all the facilities on the site and ensures the early detection of any abnormal radiological events. In addition, portable devices for the measurement of equivalent dose rate and surface activities are used regularly in time on a planned basis for control. The automated radiation 53 monitoring system is complemented by regular analyses of environmental samples (aerosols, soils, plants, underground water and rainfall) collected in the protected area [1], [4].

The presence and operation of a modern automatic radiation monitoring system allows for specialized training so that trainees are able to acquire knowledge and skills, and to prepare young professionals in the field of nuclear science and applications. The reactor IRT is visited by students in the field of nuclear physics, nuclear energy, radiochemistry, dosimetry, ecology etc. Professional retraining of specialists in the field of nuclear applications are organized.

\section{BULGARIAN AND INTERNATIONAL LEGISLATION}

The indoor radon, thoron and their decay products are the main contributors of the total inhalation dose which has long been recognized as a potential radiological health hazard [7], [8]. This led the European Council to formulate new basic safety standards for protection against ionizing radiation which cover exposure to indoor radon at home and work place as well [9]. In general, radon measurements are conducted in support to operational and radioactive contamination control goals set by the management, as well as to meet the environmental legislation and requirements of regulatory bodies.

In 2012, the International Organization for Standardization (ISO) issued guidance for measuring radon-222 and its short-lived decay products in air for three categories of measurements: spot measurement methods; continuous measurement and integrated measurement methods, ISO 11665 (Part 1 to Part 8).

In Bulgaria, the monitoring of radon concentration is not enforced yet, although there are buildings constructed in granite areas and the geological and radiological characteristics of most of these regions are well-documented. Nevertheless, the general regulations for indoor air quality were imposed by the Bulgarian legislation [10] in line with ICRP 115 and EU directives.

A radon project to elucidate the situation in kindergartens has been supported financially in 2011 . The recommendations of International Organization for Standardization (ISO 11665-1:2012, Part 4) [11] were followed and the evidence from a pilot survey of indoor radon concentration in four provinces: Sofia city, Sofia, Plovdiv and Varna is summarized in [12].

Beside national legislation [10, 13-20], the relevant standards and recommendations of IAEA [21-23] are also taken into account in solving problems at NSEEC related to radiation protection.

\section{INSTRUMENTS AND METHODS}

An ABPM 201-L and an ABPM 203-M monitor units were employed for this survey. Both units are designed as computer software-aided alpha-betagamma dosimeters. The portable computer is an essential tool for the monitor. It is used to display measurement values stored by the monitor as well as local programming (measurement channel 
programming) to evaluate radon progeny using specialized dedicated software. The measurement could be compensated for naturally occurring radioactivity (radon) and for externally induced $\gamma$ fields. The volumetric activity is measured in units selected by the operator and the unit generates visual and audible alarms whenever the threshold levels are exceeded. For calibration purposes of both monitor units either a certified ${ }^{204} \mathrm{Tl}$ source (beta detection; half-life 1380 days) with a nominal activity of $3000 \beta / \mathrm{s}$ or a certified ${ }^{238} \mathrm{Pu}$ source (alpha detection; half-life 31755 days) with a nominal activity of $3 \mathrm{kBq}$ are used. These sources are used with a designated source fixture providing fixed and repeatable geometric conditions between the source and the respective detector.

The ABPM 201-L unit measures continuously the volumetric activities of $\alpha$ and $\beta$ particulates in ambient air, discharge stacks, ventilation ducts and buildings containing radioactive material. The volumetric activity is displayed in units such as $\mathrm{Bq} / \mathrm{m}^{3}, \mathrm{Ci} / \mathrm{m}^{3}$ or other units (e.g. $\left.\mu \mathrm{Ci} / \mathrm{cm}^{3}\right)$ that can be chosen by the operator. Visual and audible alarms are caused whenever pre-set threshold levels are exceeded.

The measurement channel consists of a detection assembly comprised of a pair of large-surface area (450 $\mathrm{mm}^{2}$ ) silicon detectors (PIPS detector) coupled with preamplifiers placed in front of a filter which traps particulates, a mass flowmeter for measuring the flow rate, necessary for the processing algorithms, as well as two pressure switches $\left(\mathrm{P}_{\min }\right.$ and $\left.\mathrm{P}_{\max }\right)$ which control the filter status (torn, clogged etc.).

The mass flowmeter provides an analog signal proportional to the flow rate value. This signal is processed by a special algorithm called "Analog input" to compute the flow rate measurement. The first $\mathrm{Si}$ detector detects the alpha-beta-gamma radiation emitted from the particulates deposited on the advancing filter. The second $\mathrm{Si}$ detector is mounted behind the first one and detects only the gamma radiation emitted from the particulates deposited on the filter as well as ambient gamma background. The analog signals provided by the detection assembly are transmitted to the associated Local Processing and Display Unit LPDU/PIPS which generates the measurement in the required unit after processing. For this processing, it is important to note that the LPDU/PIPS also uses the sampling rate value which is transmitted by the mass flow. The LPDU/PIPS also manages the filter advances.

The estimation of alpha volumetric activity could take into account a dynamic compensation of perturbation due to the presence of natural radioisotopes on the filter, alpha emitters and solid daughters of ${ }^{222} \mathrm{Rn}$ (radon) and ${ }^{220} \mathrm{Rn}$ (thoron). This estimation could therefore be representative of the artificial alpha volumetric activity.

Similarly, the estimation of beta volumetric activity could be representative of the artificial beta volumetric activity, as it could take into account dynamic gamma compensation and a dynamic compensation of perturbation due to the presence of natural radioisotopes on the filter, beta emitters and solid daughters of radon and thoron.
PIPS detector performance: a) energy range for $\alpha$ : $4.2 \mathrm{MeV}<\mathrm{E}<5.5 \mathrm{MeV}$ (U, Pu, U+Pu), for $\beta: 80 \mathrm{keV}<$ $\mathrm{E}<2 \mathrm{MeV}, \gamma-80 \mathrm{keV}<\mathrm{E}<2 \mathrm{MeV}$; b) measurement range for $\alpha$ : $10^{-2}$ to $10^{4} \mathrm{~Bq} / \mathrm{m}^{3}\left(2.710^{-13}\right.$ to $2.710^{-7} \mathrm{Ci} /$ $\mathrm{m}^{3}$ ), for $\beta: 1$ to $10^{6} \mathrm{~Bq} / \mathrm{m}^{3}\left(2.710^{-11}\right.$ to $\left.2.710^{-4} \mathrm{Ci} / \mathrm{m}^{3}\right)$.

The ABPM 201-L unit uses a filter (millipore FSLW) with efficiency (for $1 \mathrm{~m} / \mathrm{s}$ ): > $99.59 \%$ for particles with an effective size $(\Phi)$ of $0.15 \mu \mathrm{m},>99.63$ $\%$ for $\Phi$ of $0.4 \mu \mathrm{m}$, > $99.99 \%$ for $\Phi$ of $4 \mu \mathrm{m}$. The standard flow rate is $35 \mathrm{l} / \mathrm{min}$.

The ABPM 203-M is an autonomous mobile and portable unit for contamination surveillance in a broad temperature range: $-25^{\circ} \mathrm{C}$ to $+55^{\circ} \mathrm{C}$. It is equipped with a special pump and serves to continuously monitor $\alpha$ and $\beta$ volumetric activity of airborne particulates in the atmosphere of nuclear installations.

The pump is installed downstream of the detector and it draws ambient air through the particulate filter at a nominal flow rate of $35 \mathrm{l} / \mathrm{min}$. This flow rate is higher than the human respiratory rate. This means that the response of the monitor to detect radiation is fast enough to alert the operator of the presence of a dangerous concentration of airborne radioactive particulate. The sampled air is discharged downstream of the pump. Radioactive particulates present in the air are trapped on a cellulose fibrous filter placed inside the CE2Oo detector. A large-area silicon detector located in front of the filter detects $\alpha, \beta$ and $\gamma$ radiation emitted by the deposited particulates. An identical second detector, placed immediately behind the first, detects only $\gamma$ radiation. The gamma measurement enables dynamic background compensation to the net particulate activity measurements. The data can also be used to display the ambient dose rate referenced to

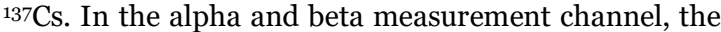
detected pulse frequency is proportional to the activity deposited on the filter. The pulse frequency of the $\gamma$ channel is associated with the ambient dose rate.

The CE 200 detector consists of 2 units: the upper unit contains 2 identical large area silicon detectors. The first detector, located in front of the filter, detects $\alpha, \beta$ and $\gamma$ activity emitted by the particulates deposited on the filter. The second detector, placed immediately behind the first, detects only $\gamma$ radiation. The gamma measurement enables background compensation to the actual particulate activity measurements. The data can also be used to display the ambient dose rate

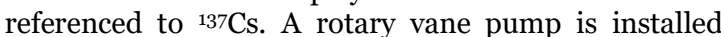
downstream of the sensor; it draws ambient air through a particulate filter. The flow rate is measured by a mass flow meter. It can be adjusted at a valve situated at the pump intake piping. The flow rate is displayed on the LPDU screen. The mass flow meter is situated at the inlet of the pump air intake. It measures the air flow rate passing through the filter and transmits this information in the form of an analog signal from 1 to 5 volts to the LPDU. This analog input is converted by a specific algorithm into a flow rate measurement. The flow rate is used by the LPDU algorithms to calculate the volumetric activity of radioactive particulates. The sampled air is discharged downstream of the pump.

The airborne radioactive particulates are deposited on the filter facing the $\mathrm{Si}$ detector which detects the 
charged particulates by generating pulses proportional to the energy lost by the particulates. Specific algorithms are used to estimate corresponding volumetric activity.

Si detector performance: $a$ ) energy range for $\alpha$ : 2.0 $\mathrm{MeV}<\mathrm{E}<4.4 \mathrm{MeV}$, for $\beta$ : $80 \mathrm{keV}<\mathrm{E}<420 \mathrm{keV}$, 80 $\mathrm{keV}<\mathrm{E}<420 \mathrm{keV} ; b$ ) measurement range for $\alpha: 10^{-2}$ to $10^{4} \mathrm{~Bq} / \mathrm{m}^{3}\left(2.710^{-13}\right.$ to $\left.2.710^{-7} \mu \mathrm{Ci} / \mathrm{cm}^{3}\right)$, for $\beta: 1$ to $10^{6}$ $\mathrm{Bq} / \mathrm{m}^{3}\left(2.710^{-11}\right.$ to $2.710^{-5} \mu \mathrm{Ci} / \mathrm{cm}^{3}$.

Minimum Detectable Activity (MDA at 2 sigma) for $\beta$ detection is as follows:

- With background compensation - Radon activity of $10 \mathrm{~Bq} / \mathrm{m}^{3}$; environmental conditions (o.1 $\left.\mu \mathrm{Gy} / \mathrm{h}\right)$ : $1.95 \mathrm{~Bq} / \mathrm{m}^{3}$ in 60 minutes

- With background compensation - Radon activity of $1 \mathrm{~Bq} / \mathrm{m}^{3}$; environmental conditions (o.1 $\left.\mu \mathrm{Gy} / \mathrm{h}\right)$ : $0.87 \mathrm{~Bq} / \mathrm{m}^{3}$ in 60 minutes

Minimum Detectable Activity (MDA at 2 sigma) for a detection is as follows:

- With background compensation - Radon activity of $10 \mathrm{~Bq} / \mathrm{m}^{3}$; environmental conditions $(0.1 \mu \mathrm{Gy} / \mathrm{h})$ : MDA: $0.13 \mathrm{~Bq} / \mathrm{m}^{3}$ in 60 minutes)

- With background compensation - Radon activity of $1 \mathrm{~Bq} / \mathrm{m}^{3}$; environmental conditions (o.1 $\left.\mu \mathrm{Gy} / \mathrm{h}\right)$; MDA: $0.071 \mathrm{~Bq} / \mathrm{m}^{3}$ in 60 minutes.

The ABPM 203-M monitor was rapidly introduced in each room or space subjected to radon control with a hose height at approximately $100 \mathrm{~cm}$ above the floor: breathing zone during the decontamination activities related to the partial dismantling of the reactor [1], [2].

\section{RESUlTS AND DisCUSSION}

The results for the gamma background levels of the NSEEC site monitored continuously by the ARMS vary in the limits $0.08 \mu \mathrm{Sv} \mathrm{h}{ }^{-1}-0.13 \mu \mathrm{Sv} \mathrm{h}{ }^{-1}$ for time span of more than 20 years. The average monthly values measured at all six control points included in the ARMS show minor seasonal variation. Gamma background data recorded for the protected area since 1961, although with other means for control, are in the same limits and indicate the quality of organization of the radiation safety control at the IRT-Sofia site throughout the time of active use of the research reactor and the long period of time afterwards.

\subsection{Radon concentration outdoor}

The large number of measurements conducted through many years with the ARMS system for environmental monitoring defined relatively constant levels of radon concentration in the supervised area of NSEEC. Slight variations in different seasons were observed in the vicinity of the research reactor but the radon concentration levels generally remain relatively constant. The measured radon concentration in the supervised area is $0.28 \pm 0.18 \mathrm{~Bq} \mathrm{~m}^{-3}$. Somewhat higher levels of radon concentration were recorded mainly in summer. It is to note that the height of ambient air sampling nozzles of the $3 \mathrm{ABPM}$ 201-L monitors in the site is fixed at $1.70 \mathrm{~m}$ above the ground to favor absorbed dose evaluation for public as well as to follow the gaseous discharge of IRT reactor when operational.

\subsection{Radon concentration in the indoor air}

In the IRT-Sofia building, ventilation systems managed locally or centrally are used to maintain the radioactivity levels within permitted limits as well as to control the gaseous releases. Exceptions are the auxiliary building hosting the laundry and the building hosting the central alarm post.

Fig. 3 and Fig. 4 (continuation) show results from the committed study aimed to track the build-up pattern of radon concentration in the laundry premises at minimal disturbance of radon atmosphere. A rapid increase of radon activity was observed after closing of the door, followed by a less pronounced radon curve; in some two hours radon activity values of approximately $80-120 \mathrm{~Bq} \mathrm{~m}^{-3}$ were already set. The dip in the curve reflected the filter advancement and reset of counting. The values continued increasing after an additional airtightening of the premises, Fig. 4 a. Opening of the entrance door and windows has an immediate effect on radon concentration, Fig. 4, c.

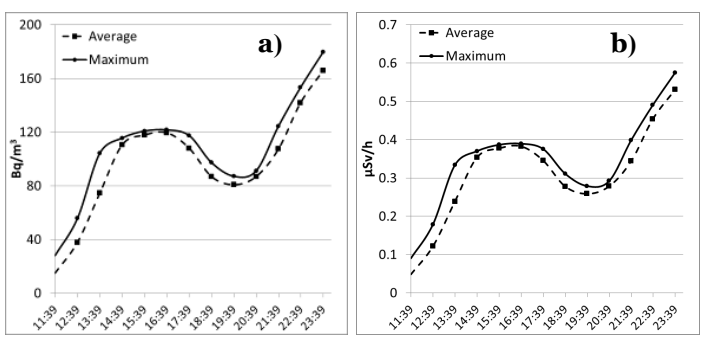

Figure 3. Laundry: a) ${ }^{222} \mathrm{Rn}$ Activity; b) Effective Dose rate

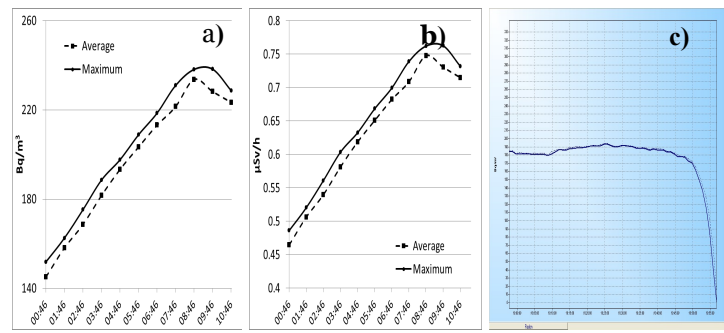

Figure 4. Laundry: Before ventilation: a) ${ }^{222} \mathrm{Rn}$ activity, b)

Effective dose rate; After ventilation: c) ${ }^{222} \mathrm{Rn}$ activity

The radon activity curve in the Central Alarm Post (CAP) behaves in a similar way, Fig. 5. Shortly after air tightening of the premises, a radon activity plateau approximately $80 \mathrm{~Bq} \mathrm{~m}^{-3}$ is observed.

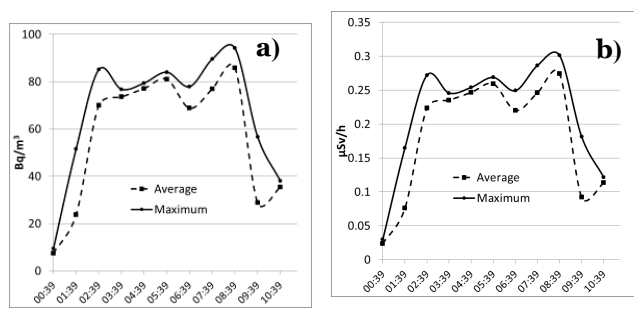

Figure 5. CAP: a) ${ }^{222} \mathrm{Rn}$ activity; b) AEffective dose rate

Both effects on radon, fast slopes at the beginning of detection and saturation in a short time, indicate 
A. Mladenov, K. Krezhov, Radon concentration measurements..., Rad. Applic., 2018, 3, 1, 52-58

that the radon atmosphere in the laundry and the CAP was already near to its maximum saturation concentration.

Many of the dismantling activities related to the IRT research reactor refurbishment project were carried out using the equipment located in the premises of the First Class Radiochemistry Laboratory (RCL-I class), presented schematically in Fig. 6 and in the Reactor Hall, Fig. 12.

Figures 7, 8, 9 and 10 show the results from measurements in room 049 (chemical laboratory), room 065 (laboratory with glove boxes on first line), room 018 (storage of environmental samples) and room 043 (second line glove boxes).

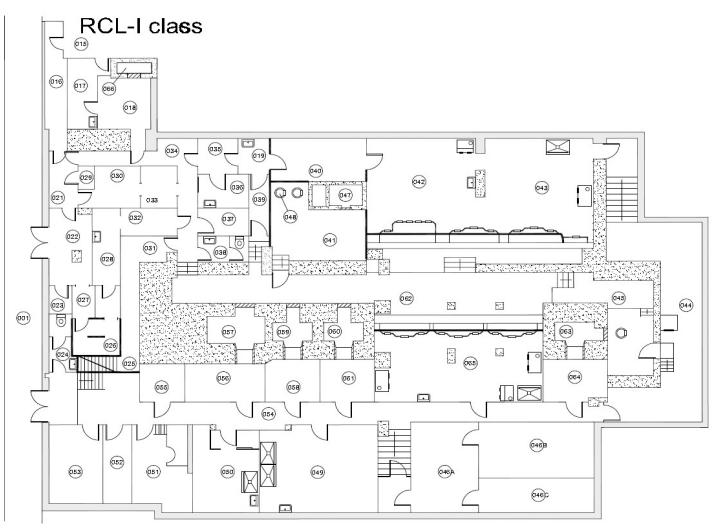

Figure 6. Schematic layout of the Radiochemistry LaboratoryI Class in IRT-Sofia basement

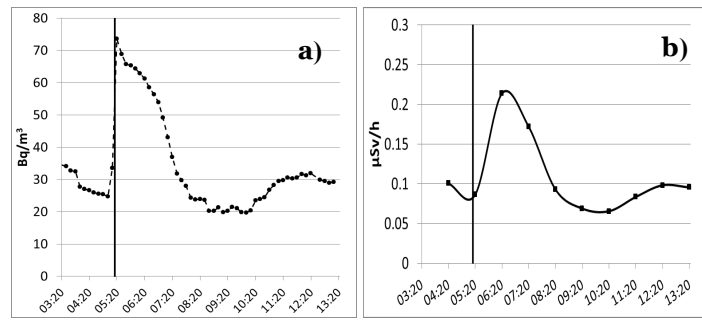

Figure 7. Measurements in RCL, room 018: a) 222Rn activity; b) Effective dose rate. The vertical line marks restart of measurements after switching on the forced ventilation again

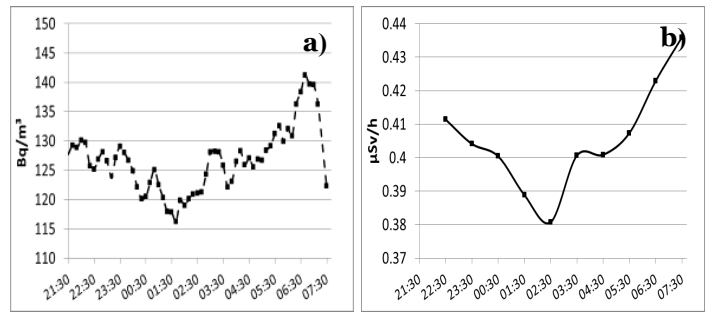

Figure 8. Measurements in RCL, room 065 : a) ${ }^{222} \mathrm{Rn}$ activity; b) Effective dose rate

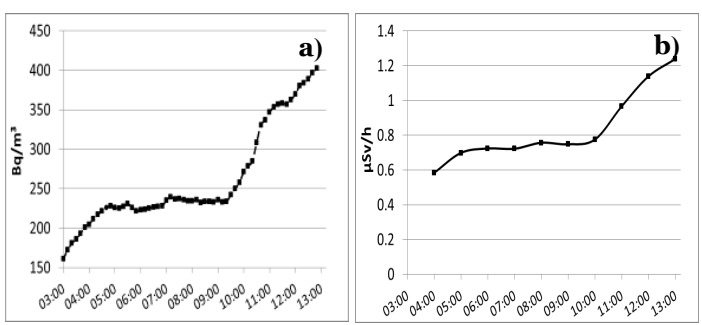

Figure 9. Measurements in RCL, room 049: a) ${ }^{222} \mathrm{Rn}$ activity; b) Effective dose rate

The dismantling of the research reactor facilities and equipment was executed in two stages [2]. The first stage comprised the dismantling of the equipment inside the reactor pool and the block with shutters of the thermal column. Fig. 11 illustrates some of the activities executed in the second stage which included dismantling of the piping and pumps in the primary cooling loop (PCL) room and Fig. 13 shows results from some measurements related to the dose burden of personnel.
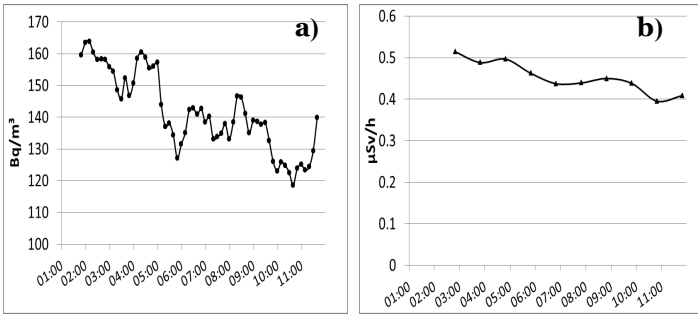

Figure 10. Measurements in RCL, room 043: a) ${ }^{222} \mathrm{Rn}$ activity; b) Effective dose rate

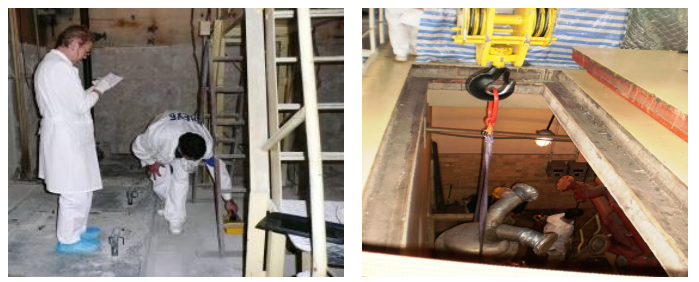

Figure 11. Tracking and record-keeping: measurements of surface contamination of the primary cooling loop premises

A simple, inexpensive and successful mitigation action for the reactor hall (Fig. 12) was to open the big entrance transport door not very far from Point 3, keeping the mean radon concentration less than 200 $\mathrm{Bq} \mathrm{m}^{-3}$ in the whole space.

In general, taking into account the high variability of the radon concentration within the different premises of the buildings, the room occupation factor and correspondence with scheduled ventilation should be considered for more accurate estimation of effective dose accumulated. 
A. Mladenov, K. Krezhov, Radon concentration measurements..., Rad. Applic., 2018, 3, 1, 52-58

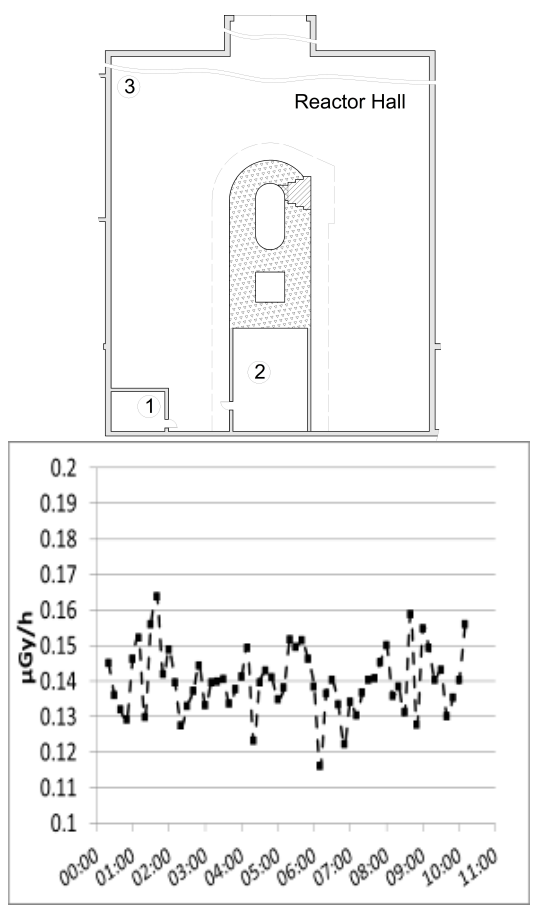

Figure 12. Left: Reactor Hall with 3 basic check points for radon concentration measurements including the PCL room

(Point 2); Right: Absorbed gamma dose rate in Point 3
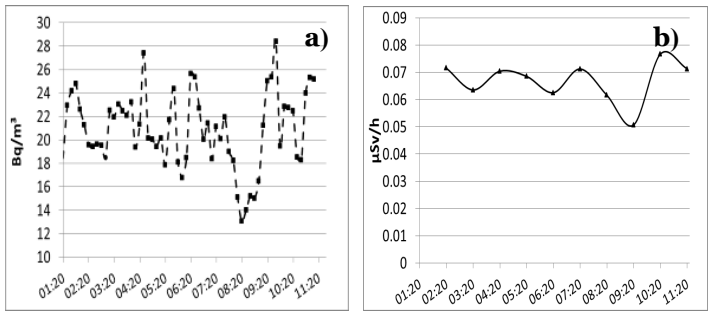

Figure 13. PCL room (Point 2):

a) ${ }^{222} \mathrm{Rn}$ activity; b) Effective dose rate

\section{CONCLUSIONS}

The objectives of the monitoring program were to determine the distribution of radon levels in the buildings, to disclose areas where the risk of exposure to radon exceeds the established radiation protection safety threshold, to evaluate possible radon risk to the public and workers, and to evaluate the effectiveness of control measures on radon levels throughout individual rooms and hallways in the IRT-Sofia building. The proper work planning and implementation was considered central to achieving the goals.

The long-term radiation measurements and site monitoring at the NSEEC provide evidence that the radon management, as developed and adopted, meets all the requirements for radiation safety of personnel and prevents any radiation consequences to the public. The measures taken to keep the volumetric activity of air in working areas and corridors well below the reference level of $1000 \mathrm{~Bq} \cdot \mathrm{m}^{-3}$ for annual average activity concentration of ${ }^{222} \mathrm{Rn}$ in working places and
300 Bq.m ${ }^{-3}$ in multipurpose public edifices have proved their efficiency.

Acknowledgement: This research is partially funded from the Bulgarian National Fund for Science under grant EO2/3 2014. The authors express sincere thanks to the NSEEC colleagues for helpful discussions and hints for the safe management of radon levels in the workplaces and training premises.

\section{REFERENCES}

1. Tz. Nonova, D. Stankov, Al. Mladenov, K. Krezhov, "Radiological characterization activities during the partial dismantling of the IRT - Sofia research reactor facilities,” Roman. J. Phys., vol. 59, no. 9-10, pp. 976 988, 2014.

Retrieved from: http://www.nipne.ro/rjp/2014_59 910/0976 0988.pdf;

Retrieved on: Nov. 24, 2017

2. I. S. Dimitrov, Tz. Nonova, Al. Mladenov, K. Krezhov, "Radiation levels at carrying out the refurbishment of the Bulgarian research reactor IRT-2000," Radiation and Applications, vol. 1, no. 1, pp. 62 - 68, Apr. 2016. DOI: 10.21175/RadJ.2016.01.12

3. Al. Mladenov, D. Stankov, Tz. Nonova, K. Krezhov. "Radiation protection, radioactive waste management and site monitoring at the Nuclear Scientific Experimental and Educational Centre IRT-Sofia at INRNE - BAS," Rad. Prot. Dosim., vol. 1, no. 1-2, pp. 176 - 181, Jul. 2014.

DOI: $10.1093 / \mathrm{rpd} / \mathrm{ncu} 254$ PMid: 25071246

4. Al. Mladenov, Tz. Nonova, D. Dimitrov, K. Krezhov, "Radioactive Waste Management at the Nuclear Scientific and Experimental Centre of Institute for Nuclear Research and Nuclear Energy - BAS," Radiation and Applications, vol. 1, no. 3, pp. 193 - 198, Dec. 2016. DOI: 10.21175/RadJ.2016.03.036

5. A. Sakoda, Y. Ishimori, K. Yamaoka, "A comprehensive review of radon emanation measurements for mineral, rock, soil, mill tailing and fly ash," Appl. Radiat. Isotopes, vol. 69, no. 10, pp. 1422 - 1435, Oct. 2011. DOI: 10.1016/j.apradiso.2011.06.009 PMid: 21742509

6. P. Bossew, "Mapping the geogenic radon potential and estimation of radon prone areas in Germany," Radiation Emergency Medicine, vol. 4, no. 2, pp. 13 20, 2015 .

Retrieved from: http://crss.hirosaki-u.ac.jp/wpcontent/files_mf/1465449240rem_vol42_03_peter_b ossew2.pdf;

Retrieved on: Nov. 24, 2017

7. Lung Cancer Risk from Radon and Progeny and Statement on Radon, ICRP Publication 115, ICRP, Ottawa, Canada 2010.

DOI: 10.1016/j.icrp.2011.08.011

PMid: 22108246

8. H. Zeeb, F. Shannoun, WHO handbook on indoor radon - a public health perspective, WHO, Geneva, Switzerland, 2009.

Retrieved from: http://apps.who.int/iris/bitstream/106 65/44149/1/9789241547673 eng.pdf; Retrieved on: Nov. 24, 2017

9. European Council. (Dec. 5, 2013). Council Directive 2013/59/EURATOM laying down basic safety standards for protection against the dangers arising from exposure to ionising radiation, and repealing Directives 89/618/Euratom, 90/641/Euratom, 
A. Mladenov, K. Krezhov, Radon concentration measurements..., Rad. Applic., 2018, 3, 1, 52-58

96/29/Euratom, 97/43/Euratom and 2003/122/Euratom.

10. Агенция за ядреного регулиране. (25.09.2012). Но. 229 Наредба за основните норми за радиациона защита. (Bulgarian Nuclear Regulatory Agency. (Sep. 9, 2012). No. 229 Regulation on Basic Norms of Radiation Protection.)

Retrieved from: http://www.bnra.bg/bg/documents/le gislation/regulations/reg-onrz-2012.pdf;

Retrieved on: Nov. 24, 2017

11. Measurement of radioactivity in the environmentAir, Part 4: Radon-222: integrated measurement methods for the determination of the average radon activity concentration in the atmospheric environment using passive sampling and delayed analysis, ISO 11665-1:2012, Nov. 29, 2012.

Retrieved from:

https://www.iso.org/standard/52187.html; Retrieved on: Nov. 24, 2017

12. K. Ivanova, Z. Stojanovska, M. Tsenova, V. Badulin, B. Kunovska, "Measurement of indoor radon concentration in kindergartens in Sofia, Bulgaria," Rad. Prot. Dosim. vol. 162, no. 1-2, pp. 163 - 166, Nov. 2014. DOI: $10.1093 / \mathrm{rpd} / \mathrm{ncu} 251$

13. Bulgarian Nuclear Regulatory Agency. (Sep. 2, 2004). No. 231 Regulation on Ensuring the Safety of Research Nuclear Installations.

Retrieved from: http://www.bnra.bg/en/documentsen/legislation/regulations/reg-rr-en.pdf;

Retrieved on: Nov. 24, 2017

14. Bulgarian Nuclear Regulatory Agency. (Aug. 24, 2004). No. 74/08.09.2006 Regulation for radiation protection during activities with sources of ionizing radiation.

Retrieved from: http://www.bnra.bg/en/documentsen/legislation/regulations/reg-radprot-2012-en.pdf; Retrieved on: Nov. 25, 2017

15. Bulgarian Nuclear Regulatory Agency. (May 18, 2004). No. 41/18.05.2004 Regulation on the procedure for issuing licenses and permits for safe use of nuclear energy.

Retrieved from: http://www.bnra.bg/en/documentsen/legislation/regulations/reg-licence-en.pdf; Retrieved on: Nov. 25, 2017

16. Bulgarian Nuclear Regulatory Agency. (Feb. 20, 2015). Act on the Safe Use of Nuclear Energy.

Retrieved from: http://www.bnra.bg/en/documentsen/legislation/laws/zbiae2012-en.pdf; Retrieved on: Nov. 25, 2017

17. Министерство на здравеопазването. (7.11.2005). Наредба Но. 32 за условията и реда за извършване на индивидуален дозиметричен контрол на лицата, работещи с източници на йонизиращи лъчения. (Minitry of Health. (Nov. 7, 2005). Regulation № 32 on the terms and conditions for individual dosimetric control of the persons working with sources of ionizing radiation.)
Retrieved from: http://www.mh.government.bg/media Lfiler_public/2015/04/22/naredba32-ot-7-11-2005gindividualen-dizometrichen-kontrol-ionizirashtilachenia.doc;

Retrieved on: Nov. 25, 2017

18. Министерство на здравеопазването. (16.9.2005). Наредба Но. 29 за здравни норми и изисквания при работа в среда на йонизиращи лъчения. (Ministry of Health. (Sep. 16, 2005). Regulation №29 on health standards and requirements at work in ambience of ionizing radiation.)

Retrieved from: http://econ.bg/Нормативниактове/Наредба-29-от-16-септември-2005-г-заздравни-норми-и-изисквания-при-работа-в-средана-йонизиращи- l.1 i.127032 at.5.html; Retrieved on: Nov. 25, 2017

19. Bulgarian Nuclear Regulatory Agency. (05.10.2012). Regulation on the Procedure for Issuing Licenses and Permits for Safe Use of Nuclear Energy, Promulgated in the State Gazette No. 41/18.05.2004, Amended SG No. 78/30.09.2005; 93/24.11.2009; 76/05.10.2012. Retrieved from: https://gnssn.iaea.org/CSN/School\%2 oof\%20Drafting\%20Regulations\%20Nov\%202014/Sch ool\%20of\%20drafting\%20Nov\%202014\%20Backgroun d\%20information/Participants\%27\%20materials/Bulg aria\%20-reg-licensing-2012-en.pdf; Retrieved on: Nov. 25, 2017

20. Bulgarian Nuclear Regulatory Agency. (5.10.2012). Regulation for radiation protection during activities with sources of ionizing radiation, amended State Gazette No 76/5.10.2012.

Retrieved from: http://www.bnra.bg/en/documentsen/legislation/regulations/reg-radprot-2012-en.pdf; Retrieved on: Nov. 25, 2017

21. Radiation Protection and Radioactive Waste Management in the Design and Operation of Research Reactors, Safety Guide No. NS-G-4.6, IAEA, Vienna, Austria, 2008.

Retrieved from: https://www-

pub.iaea.org/MTCD/publications/PDF/Pub1369 web. pdf;

Retrieved on: Nov. 25, 2017

22. Safety considerations for research reactors in extended shutdown, IAEA-TECDOC-1387, IAEA, Vienna, Austria, 2004. Retrieved from: https://wwwpub.iaea.org/MTCD/publications/PDF/te 1387 web.p df;

Retrieved on: Nov. 25, 2017

23. Environmental and Source Monitoring for Purposes of Radiation Protection, Safety Guide No. RS-G-1.8, IAEA, Vienna, Austria, 2012.

Retrieved from: https://wwwpub.iaea.org/MTCD/Publications/PDF/Pub1216 web. pdf;

Retrieved on: Nov. 25, 2017 